\title{
The Influence of Interlocking Directorates on the Propensity of Dividend Payout to the Parent Company
}

\author{
Dariusz Siudak (D) \\ Lodz University of Technology, Institute of Social Sciences and Management of Technologies, Lodz, Poland \\ Correspondence should be addressed to Dariusz Siudak; dariusz.siudak@p.lodz.pl
}

Received 26 February 2020; Accepted 22 April 2020; Published 27 May 2020

Guest Editor: Thiago Christiano Silva

Copyright (c) 2020 Dariusz Siudak. This is an open access article distributed under the Creative Commons Attribution License, which permits unrestricted use, distribution, and reproduction in any medium, provided the original work is properly cited.

\begin{abstract}
An examination was performed on whether director interlocks enabled the adoption of a dividend policy for the benefit of the parent company in the ownership structure. Specifically, the study investigated the dependence of the impact of the central position in the board network on the probability of dividend payment. Based on sample of firms listed on Polish capital market, it was observed that the more central the company's position in the interlocking directorate network, the more likely it is to pay dividends to a subsidiary. This effect is related to the eigenvector centrality. The results obtained suggest that corporate financial policy can be spread across firms through the board network.
\end{abstract}

\section{Introduction}

The network of business connections through the interlocking directorates is a complex network. A complex network can be described as a graph that consists of vertices and edges that reveal topological properties and interrelationships [1]. The participation of a company in a network with such properties results in diversification of emerging effects whose impact on the network diffusion of multiple corporate practices is highly complex through nonlinear interactions between a large number of individual components of the entire system. The inability to explain the overall functioning of the system by determining the properties, structure, and understanding of the operation of separate components of the system constitutes a complex system.

The network perspective sees markets in the form of business networks [2]. One of the possible network connections is interlocking directorates. A relationship is created when one person sits in the boards of at least two companies. Interlocking directorates exist globally and have been studied by management scholars, economists, and organizational sociologist [3].

Pfeffer and Salancik [4] described board networks as a form of interorganizational relationship that facilitates interaction between the company over time. The links thus created between several enterprises lead to the creation of a communication network in which information flows. A communication network is a system of relationships created by the flow of data, information, knowledge, images, symbols, and other forms of messages between selected points of the network among objects in time and space [5]. Interlocking directorates are a common element of the capital market in geographical and temporal space, resulting from corporate governance. The theory of social networks suggests that interorganizational networks have the ability to influence relationships among enterprises, are also carriers of information from the external environment of organizations and are used as mechanisms of diffusion of organizational practices, including financial policies of enterprises.

The board of directors and the interlocking directorate network created through it is an important element of corporate governance. The company often consciously decides to establish relations with other companies by joining the interlocking network. This can be carried out by accepting an external board member from another organization or by delegating a director to the board of directors of another company. In this respect, the relational strategy can be discussed. Relationship strategy using interlocking directorates is the most flexible and easily implemented [4] 
as well as the most widely used in the external environment of the organization $[6,7]$. This strategy is applied especially in cases where the enterprise operates in conditions of uncertainty, interorganizational interdependence, control of other organizations, organizational complexity, concentrated ownership structure, and inability to legalize ownership links. Access to information and organizational practices of other companies are the main benefits of interlocking, which leads to higher board of directors' effectiveness [8]. The information obtained from the network may be used by the board of directors to assess the situation of their own company and planned actions. The board of directors is therefore the key to the success of the relational strategy.

The interlocking directorate network enables the mechanism of diffusion of ideas, strategies, practices, and organizational solutions. For a company, the application of a relational strategy using its own board of directors in the creation of relationships in the interlocking network enables the launch of a channel for the adoption of business practices. In other words, participation in the board network enables the absorption of knowledge. Launching and maintaining this channel through the interlocking directorate network are achievable at low cost.

The aim of the paper was to analyze the impact of participation in the interlocking directorate network on the decision to pay dividends. The spread of dividend policy between firms in the corporate board network was examined. In particular, an attempt was made to answer the research question whether board interlocks ties in the network increase the probability of dividend payment to the parent company? In other words, is there a network diffusion of organizational practice concerning dividend policy? These questions identified a research gap in the literature, where the aim of the research was to fill this gap.

Network analysis suggests that information diffuses through networks, and firms that occupy a privileged position in the network can make more sophisticated (or informed) decision [9] in various areas of business management. It is believed that taking the central position of a company in the board interlock network increases the probability of paying dividends to the parent company. This effect relates to eigenvector centrality, i.e., centrality, which is measured by the number of relationships with other companies in the network and their level of centrality. To the best our knowledge, this research is the first to show that the dividend policy in favor of the parent company in its ownership structure may be adopted through the board interlock network. It was only at work [10] that the adoption of the interlocking network dividend policy was discussed, but the subject of the study was the payment of dividends to all the shareholders and not only to the subsidiary. The adoption of a decision to pay dividends via the interlocking network has a direct impact on the cash flow to shareholders. The results obtained in this research suggest that corporate financial policy can be spread across firms through the board network.

This study contributes to the corporate governance, corporate finance, and social network literature. Firstly, ownership structure and conflicts of interest are part of corporate governance. The results obtained show that corporate governance should be perceived not only from the point of view of strictly economic issues but also from the point of view of interorganizational relations, assuming that organizations are not isolated individuals. The conducted relational strategy determines the complex structure of the corporate network.

Secondly, this research also adds novel insights to the literature on the impact of social networks and especially the role of director networks on corporate finance. The results of the research document the impact of information flow and diffusion of organizational practices in the board network in the area of corporate finance.

Thirdly, this research contributes to the discussion on the influence of social networks in the form of interlocking directorates on behaviors and decisions made in the organization. Network analysis tools allow for the detection of network structures that are important for the organization.

The paper is organized as follows. Section 2 presents the theoretical foundations and hypotheses. Section 3 presents the research method, research sample, and process of obtaining data. It also describes the variables used in the empirical part. Section 4 is devoted to presentation of the results of the research, and the paper closes with the discussion and final conclusions.

\section{Theoretical Foundations and Hypotheses}

The basic assumption of the research is the observation that the enterprise network is a medium of information flow and the spread of corporate practices across companies. The literature on the subject provides many examples of diffusion of strategies and business practices through the network. One of the first studies on a platform for diffusion of organizational practices through an interlocking network concerns the adoption of financial support for election campaigns by companies in the USA $[11,12]$. Further research has shown that the following organizational solutions and business practices have spread through the network: enterprise philanthropy [13]; structuring the remuneration of board members $[14,15]$; the dissemination of executive compensation practices [15-18]; poison pills [19, 20]; golden parachutes [20-22]; greenmail [23]; innovations [24-27]; new product introductions [28, 29]; multidivisional form (Mform) [30, 31]; creation of an investor relations department within the organization [32]; financial restructuring [33]; diversification [34]; board independence [35]; and implementation of quality standards [36]. In addition, the network enables strategy diffusion [37-39]; its diversification [7]; international expansion [40]; management styles [41-43]; decision-making process [44, 45]; and diffusion of business practices in general $[46,47]$. An important element of the relational strategy is the ability to transfer tacit knowledge between enterprises, which is impossible to produce or acquire on the market [48-53]. Forming board interlocks increase the likelihood of forming an R\&D alliance with the cooped enterprise [54] and auditor choice [55, 56]. A growing body of research examined the role of board networks in 
corporate financial policy, such as stock option backdating $[57,58]$; changes in the quotations of own shares between stock markets [59]; earnings management [60-62]; accounting method choice [63]; stock option expressing [64, 65]; venture capital investments [66]; corporate-owned life insurance as a tax shelter $[67,68]$; inclination to takeover other companies [69]; the payment of bonuses for acquisitions [70]; or firms become targets in change-of-control in private equity transactions [71]. It should be mentioned that sophisticated traders made by short seller, option traders, and institutional investors are more informed when trading stocks of enterprises with more interlocked boards [72]. In the field of corporate finance, it has been shown that ties in the board network reduce the implied cost of capital [73].

One of the characteristics of the interlocking directorate network is the existence of a structure called small-world networks [74-78]. In small-world networks, the structure of relationships between vertices is different from the random network structure, according to Erdös-Renyi graphs [79], and the structure of a regular network. The literature has shown that the interlocking directorate network in different time and geographical cross sections shows the characteristics of small-world networks [78, 80-91]. Also, the interlocking network on the Polish capital market shows the characteristics of small-world networks [92]. The structure of the interlocking network in accordance with the concept of small-world networks means that relationships among organizations in the network are created in a nonrandom manner. Numerous shortcuts in such a network make the speed of information flow in the small-world network higher than in the random or regular network [92]. A network with such a structure enables fast communication between unrelated organizations, even within two opposing poles of the network. The trajectory of information transfer covers even weakly networked enterprises located on the periphery of a network with a low level of centrality.

Board of directors is a significant part of the corporate governance structure $[93,94]$, as a bridge between the company and other organizations. Corporate governance mechanisms are based on principles from areas such as finance, management, and law [95]. Agencies, shareholders, management, and debt providers are three main areas of potential conflicts of interest [96]. The board of directors of a company is an important element of the internal corporate governance structure, which plays an essential role in improving the financial performance of a company [97]. The board performs critical functions in the form of monitoring, advice on strategic decisions [98], services, and provision of external resources from the organization's environment [99], where these roles are performed simultaneously [100]. One of the important functions of the board of directors is to participate in shaping the company's strategy and its implementation [101]. The role of the board of directors in the aspect of scanning strategies of other companies [7], obtaining information on the applied organizational and supervisory practices [102] and their potential adoption to their own organization, is particularly emphasized within resource dependences theory. An effective board of directors can be seen as a key corporate resource [103].
Formation of connections in the interlocking directorate network is explained on the ground of the resources dependence theory $[4,104,105]$. Resource dependence theory concludes that interlocks are welfare enhancing [3]. Relationships in the network result from the demand for resources controlled by organizations in the external environment of the enterprise. The resource dependence of an organization determines the level of uncertainty, which is further increased by the asymmetry of information. The established network links provide a response to the demand for resources and the ability to access information and coordinate activities. Acquiring resources from other organizations and reducing information asymmetry through links with other enterprises in the network translates into a general benefit which is a reduction in uncertainty. Diffusion of business practices is a prerequisite for applying a network relational strategy in the area of resources dependence theory. Based on the above-mentioned consideration the following proposition can be made.

Proposition 1. The more central the position in the network, the greater the exposure to the network information flow, increasing the possibility of adopting business practices.

Based on the experience of the networked board member, the board of directors can recommend the payment of dividends as a distribution of the company's net profit. The recommendation to allocate part or all of the net profit to dividend payment to shareholders may be dictated by the premise of increasing the company's value. Maximizing the value of an enterprise is the primary objective of its business. In accordance with the concept of value-based management, a properly defined and consistent dividend policy contributes to the increase of the company's value for shareholders. As a result, the parent company in the ownership structure accounts for a portion of the dividend due.

Company ties can be created not only via board network but also through ownership network [106]. Nicholson et al. [107] drew attention to the parallelism of networking through interlocking directorates in relation to the concentrated ownership structure. This is due to the fact that affiliated companies in the ownership network have the possibility to delegate their directors to the company board of directors of which they are the owners or major shareholders. The positive relationship between the board network and ownership network has been demonstrated in the works $[86,108-110]$. The close relationship between the two types of corporate networks also indicates a greater degree of reconstruction of accidental broken ties in the board network where both organizations have a relation in the ownership network [111]. On the contrary, interlocking links can be seen as a flexible substitute for relations in the ownership structure [112]. Interlock board network is as a result not only of resource dependence but also of corporate control and intercorporate cohesion [113].

Relationships within the interlocking directorate network are also a tool for interorganizational coordination and control of other companies. On the one hand, a company sending its director to the board of another company (initiation of relations) creates the possibility of influencing 
the key decisions of the related organization. It is possible for a company to participate in the decision-making process of enterprises with which a relationship is established, increasing its strength and influence over other companies [113]. On the other hand, as Schoorman et al. [114] pointed out, for a host company, the outside director (the relationship of reception) risks losing partial autonomy and its own control over the organization's affairs and flexibility in decision-making. For an enterprise, this is the cost of participating in an interlocking network, expecting a number of benefits related to the transfer of knowledge, information, or diffusion of organizational solutions. With this in mind, there is another reason for recommending the payment of dividends to owners as a policy of redistributing net profit generated by a subsidiary to its parent company. This applies to situations where there is a legal transfer of cash to the entity owning the subsidiary. Moreover, information from other companies about the applied solution of cash distribution from the subsidiary to the parent company may result in the adoption of this form of redistribution and cooperation of related companies on a larger scale. These relationships are based on agency theory. On this basis, the following proposition can be made.

Proposition 2. Board network links increase the control of related companies by shaping the dividend policy of the subsidiary in the light of the parent company's objective in the ownership structure.

On the basis of the above-mentioned considerations, the following hypothesis has been formulated. The higher the firm's board interlock centrality is, the higher probability that the dividend will be paid.

\section{Method}

3.1. Sample and Data Collection. The study was carried out on an undirected network of enterprises established on the basis of their relationship through the boards of directors. The network included 945 companies listed on the main market of Warsaw Stock Exchange (SWE) and the NewConnect market (NC), at the end of 2015. The boards of directors include the members of the management boards and the supervisory boards collectively (a total of 6,228 people). The board network is undirected and unweighted described by a matrix containing a dichotomous variable, where the value 1 means that there is a connection through a person sitting on at least two boards of enterprises and the value 0 in the opposite case. The network is shown in Figure 1. The information about the people sitting on the boards of directors, as well as the economic data, was obtained from the Notoria service, as of the 31st of December, 2015 (the preparation of financial statements). The study therefore concerned cross-sectional data where data were collected at the end of 2015. Due to missing data, the number of companies in the sample was finally limited to 678 firms. The dataset for the study is included in the supplementary material of this article in the file "Dataset.xlsx" (available (here)). Table 1 presented global network indicators.

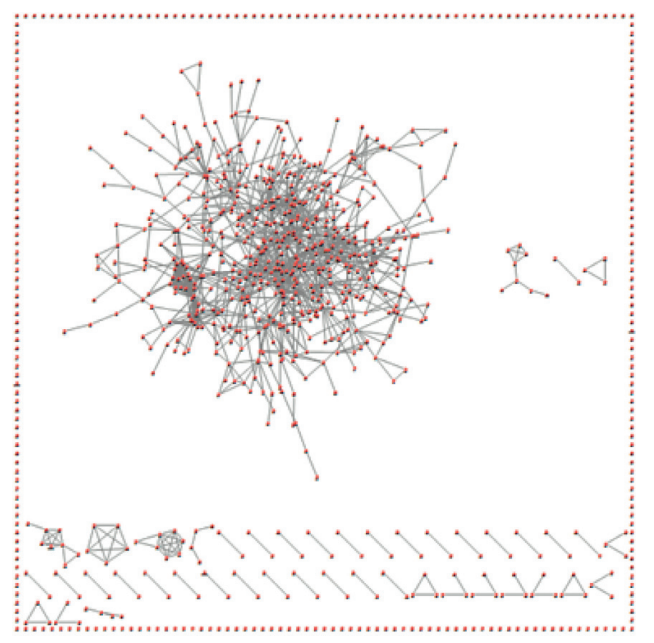

Figure 1: Network of interlocking directorates between Polish companies $(N=945)$. Visualization algorithm: stress majorization [115].

TABLE 1: Global indicators for the board network.

\begin{tabular}{lc}
\hline Variable & Value \\
\hline Number of nodes (number of companies) & 945 \\
Number of people (members of the board of directors) & 6,228 \\
Degree for the entire network (total number of & 2,698 \\
connections in the network) & 2.86 \\
Mean degree & 542 \\
Number of vertices in the largest component & $57.4 \%$ \\
Fraction of vertices in the largest component & 280 \\
Number of isolated nodes & 665 \\
Number of connected nodes & $70.37 \%$ \\
Inclusiveness & 0.003 \\
Network density & $2.35 \%$ \\
Network degree centralization index & $9.90 \%$ \\
Network closeness centralization index & $4.59 \%$ \\
Network betweenness centralization index & 0.005 \\
Mean eigenvector centrality &
\end{tabular}

\subsection{Variables}

3.2.1. Analytic Methods and Dependent Variable. Appropriate assessment of the impact of information flow in the interlocking network on the adoption of dividend payment practices was carried out using logistic regression. For this reason, the description of the variables adopted in the study was divided into dependent variable, independent variables, and control variables. In the logistic regression method, the dependent variable is the dichotomous variable. In the study design, a variable that determines whether the enterprise pays dividend to the parent company was adopted, taking two values, i.e.,

Dividend $= \begin{cases}1, & \text { when the enterprise paid dividend to the parent entity, } \\ 0, & \text { otherwise. }\end{cases}$

Regression analysis for a dichotomous dependent variable can be performed using a logistic regression model, based on a logistic function, taking a general form: 


$$
P(Y=1 \mid X)=\frac{e^{b_{0}+\sum_{i=1}^{k} b_{i} \cdot x_{i}}}{1+e^{b_{0}+\sum_{i=1}^{k} b_{i} \cdot x_{i}}},
$$

where $Y$ is the dichotomous dependent variable; $X$ is the sequence of $k$ dependent variables $\left(x_{1}, x_{2}, \ldots, x_{k}\right) ; b_{i}(i=0$, $1, \ldots, k)$ is regression coefficients; and $x_{i}(i=1,2, \ldots, k)$ is independent variables.

The maximum likelihood method is used to maximize the likelihood function. The greater the reliability, the better the model fits the data, which means a higher probability of the dichotomous value of the independent variable appearing in the test sample. Logistic regression analysis was performed using Statistica software [116].

3.2.2. Independent Variables. The first independent variable is interlock, which determines whether a company has relationships in the interlocking network. This is a dummy variable that takes the value 1 if the company has at least one relationship in the network; 0 if otherwise.

In this study, the centrality measures were taken as network variables being a tool for measuring the degree of participation in the network structure and the possibility of absorbing information from it. The centrality measures are used to quantify the interconnection of vertices in the network [117], taking into account the network structure in the spectrum of direct and indirect connections. Centrality quantifies how important nodes are in the networked system [118]. For this reason, in this study, four measures were adopted as independent variables that measured the degree of centrality of an enterprise in the interlocking directorate network:

\section{(1) Degree centrality}

(2) Closeness centrality

(3) Betweenness centrality

(4) Eigenvector centrality

Each of the proposed measures determines the central position of the vertex in the network, although the concept of centrality is formed differently for each of them. The first three measures of centrality are the most common in the literature on social networks [117-126] and used in research $[86,127-132]$. Degree is the number of edges connected to the vertex. Degree in a corporate network means the number of links with companies. Degree centrality is a simple centrality of network structure measured based on degree. It is computed by portion of nodes that are adjacent to each vertex. Closeness centrality is a measure of independence and resilience to influence [119], an index of the expected time of information flowing through the network [129]. Betweenness centrality, proposed in Freeman paper [117], is interpreted as the ability to control the flow of information in the network and to act as an intermediary of exchange between the other nodes [120], indicating the incidence of the vertex on the shortest path between the pairs of other nodes in the network. The eigenvector centrality takes into account the centrality of the nodes one is connected to, which means that the whole network model is taken into account [133]. It is a measure of the popularity and ability to transmit information through a connection with nodes that are also highly connected. This data were obtained using the NetMiner 4.4.3 [134].

3.2.3. Control Variables. In order to control the systematic variance of the impact on the payment of dividends, the following control variables have been taken into account regardless of the result in terms of the centrality of the node in the interlocking directorate network:

(1) Ln (Age), Ln (Assets), and Board size. Firm size and age were included as control variables. These variables control the firm size through the size of the board of directors, as well as the natural logarithm of the asset value and the time of listing the company on the stock exchange. It is expected that the longer the company is listed on the stock exchange and has a larger board of directors, the greater the propensity is to pay dividends.

(2) $R O A$, and $R O A_{-t-1}$. Return on assets in current year and lagged by one year. It should be noted that dividends are paid out of net profit (except when the company pays a privileged dividend and previous years). Return on assets as a profitability indicator is based on the net profit (net profit is divided by the value assets). The positive value of the profitability indicator, especially from the previous year, means that the net profit is higher than 0 and can therefore be transferred to the owners by the decision to pay dividend.

(3) Ln (Sales), Cash, Liquidity $-t-1$, and Ln (Leverage). The characteristics of the company's financial information that might affect dividend payment decision were accounted for in the logistic regressions. These control variables are the key performance indicators of the company used in the financial analysis of the company.

Table 2 presents the specification of variables used in regression models.

\section{Models and Results}

The descriptive statistics of the variables are presented in Table 3, and the correlation matrix with the significance coefficients are presented in Table 4 .

In logistic regression analysis, the minimum size of a given group must meet the condition $N>10(k+1)$, where $k$ is the number of independent variables. Therefore, the minimum group size for 14 independent variables is 151 , which is fulfilled. The smallest group for companies that pay dividend is 240 cases, which is larger than the minimum group size. In addition, the total sample is 678 cases, which is much larger than the recommended sample of at least 500 elements.

The further part of the analysis presents the results of logistic regression analysis, where the dividend was adopted as the dichotomous dependent variable, and the modeling is for the dividend payment (Dividend =1).

In the formulated hypothesis, it was predicted that the dissemination of corporate practices among board interlocks may influence a firm's dividend policy for the benefit of the 
TABLE 2: Specification of variables used in regression models.

\begin{tabular}{|c|c|c|}
\hline Type of variables & Variable & Operationalization \\
\hline $\begin{array}{l}\text { Dependent } \\
\text { variable }\end{array}$ & Dividend & Dividend $= \begin{cases}1, & \text { when the enterprise paid dividend to the parent entity } \\
0, & \text { otherwise }\end{cases}$ \\
\hline \multirow{6}{*}{$\begin{array}{l}\text { Independent } \\
\text { variables }\end{array}$} & Interlock & Interlock $= \begin{cases}1, & \text { when the company has at least one relationship in the network } \\
0, & \text { otherwise }\end{cases}$ \\
\hline & Degree centrality & $\begin{array}{l}\text { The number of links with other companies in an interlocking network } \\
\mathrm{DC}_{i}=\left(d_{i} /(N-1)\right)=\left(\sum_{j=1}^{N} a_{i j} /(N-1)\right)(i \neq j) \text { where } d_{i} \text { is thedegree of vertex } i, N \text { is the number of } \\
\text { vertices in the network, and } a_{i j} \text { is the elements of the adjacency matrix } \mathbf{A} \text {, where }\end{array}$ \\
\hline & & $a_{i j}= \begin{cases}1, & \text { if there is a link between vertices } i \text { and } j \\
0, & \text { otherwise }\end{cases}$ \\
\hline & centrality & $\mathrm{CC}_{i}=\left((N-1) / \sum_{j=1}^{N} l_{i j}\right)(j \neq i), l_{i j}$ is geodesic distance connecting $i$ and $j$ \\
\hline & $\begin{array}{l}\text { Betweenness } \\
\text { centrality }\end{array}$ & $\begin{array}{c}\mathrm{BC}_{k}=\left(\sum_{i<j}\left(g_{i k j} / g_{i j}\right) /((N-1)(N-2) / 2)\right)(i \neq j \neq k) \text {, where } g_{i k j} \text { is the number of geodesic paths } \\
\text { connecting } i \text { and } j \text { through } k \text { and } g_{i j} \text { is the total number of geodesic paths connecting } i \text { and } j\end{array}$ \\
\hline & $\begin{array}{l}\text { Eigenvector } \\
\text { centrality }\end{array}$ & $\begin{array}{c}e_{i}=\lambda \sum_{j=1}^{N} a_{i j} \cdot e_{j}(i \neq j) \text {, where } \lambda \text { is the proportionality constant (eigenvalue), } e_{j} \text { is the eigenvector } \\
\text { centrality score, and } a_{i j} \text { is the }(i, j) \text { entry of the adjacency matrix } \mathbf{A}\end{array}$ \\
\hline \multirow{9}{*}{$\begin{array}{l}\text { Control } \\
\text { variables }\end{array}$} & Ln (age) & The natural logarithm of the total years the company has been listed on Polish stock exchange \\
\hline & Board size & Total number of persons on the board of directors \\
\hline & Ln (assets) & The natural logarithm of the total assets \\
\hline & ROA & Return on assets, $\mathrm{ROA}=($ net profit/assets $) \cdot 100 \%$ \\
\hline & ROA_t $t-1$ & Return on assets lagged by one year \\
\hline & Ln (sales) & The natural logarithm of the revenue \\
\hline & Cash & Ratio of cash flow to total assets \\
\hline & Liquidity_t-1 & Cash ratio lagged by one year (ratio of cash to payments required immediately) \\
\hline & Ln (leverage) & The natural logarithm of the ratio of total long-term debt to total assets \\
\hline
\end{tabular}

parent company in the ownership structure. To test this prediction, we perform the following regression models:

$$
\begin{aligned}
& \operatorname{logit} P=\alpha_{0}+\alpha_{1} \operatorname{Ln}(\text { Age })_{i}+\alpha_{2} \text { BoardSize }_{i}+\alpha_{3} \operatorname{Ln}(\text { Assets })_{i}+\alpha_{4} \mathrm{ROA}_{i}+\alpha_{5} \mathrm{ROA}_{-} t-1_{i}+\alpha_{6} \operatorname{Ln}\left(\text { Sales }_{i}+\alpha_{7} \mathrm{Cash}_{i}\right. \\
& +\alpha_{8} \text { Liquidity_t } t-1_{i}+\alpha_{9} \operatorname{Ln}(\text { Leverage })_{i}+\varepsilon_{i} \text {, } \\
& \operatorname{logit} P=\alpha_{0}+\alpha_{1} \text { Interlock }+\alpha_{2} \operatorname{Ln}(\text { Age })_{i}+\alpha_{3} \text { BoardSize }_{i}+\alpha_{4} \operatorname{Ln}(\text { Assets })_{i}+\alpha_{5} \text { ROA }_{i}+\alpha_{6} \text { ROA } \_t-1_{i}
\end{aligned}
$$

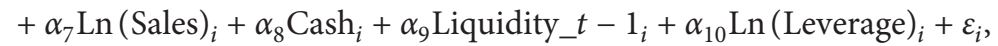

$$
\begin{aligned}
& \text { logit } P=\alpha_{0}+\alpha_{1} \text { Degree centrality }+\alpha_{2} \operatorname{Ln}(\text { Age })_{i}+\alpha_{3} \text { BoardSize }_{i}+\alpha_{4} \operatorname{Ln}(\text { Assets })_{i}+\alpha_{5} \mathrm{ROA}_{i}+\alpha_{6} \mathrm{ROA}_{-} t-1_{i}+\alpha_{7} \operatorname{Ln}(\text { Sales })_{i}
\end{aligned}
$$

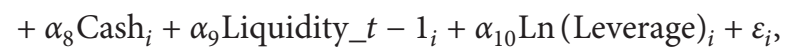

$$
\begin{aligned}
& \operatorname{logit} P=\alpha_{0}+\alpha_{1} \text { Closeness centrality }+\alpha_{2} \operatorname{Ln}(\text { Age })_{i}+\alpha_{3} \text { BoardSize }_{i}+\alpha_{4} \operatorname{Ln}(\text { Assets })_{i}+\alpha_{5} \mathrm{ROA}_{i}+\alpha_{6} \mathrm{ROA}_{-} t-1_{i}+\alpha_{7} \operatorname{Ln}(\operatorname{Sales})_{i}
\end{aligned}
$$

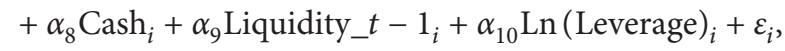

$$
\begin{aligned}
& \operatorname{logit} P=\alpha_{0}+\alpha_{1} \text { Betweenness centrality }+\alpha_{2} \operatorname{Ln}(\text { Age })_{i}+\alpha_{3} \text { BoardSize }_{i}+\alpha_{4} \operatorname{Ln}(\text { Assets })_{i} \\
& +\alpha_{5} \mathrm{ROA}_{i}+\alpha_{6} \text { ROA } \_t-1_{i}+\alpha_{7} \operatorname{Ln}(\text { Sales })_{i}+\alpha_{8} \text { Cash }_{i}+\alpha_{9} \text { Liquidity } \_t_{-}-1_{i}+\alpha_{10} \operatorname{Ln}(\text { Leverage })_{i}+\varepsilon_{i}, \\
& \operatorname{logit} P=\alpha_{0}+\alpha_{1} \text { Eigenvector centrality }+\alpha_{2} \operatorname{Ln}(\text { Age })_{i}+\alpha_{3} \text { BoardSize }_{i}+\alpha_{4} \operatorname{Ln}(\text { Assets })_{i} \\
& +\alpha_{5} \mathrm{ROA}_{i}+\alpha_{6} \text { ROA } \_t-1_{i}+\alpha_{7} \operatorname{Ln}(\text { Sales })_{i}+\alpha_{8} \text { Cash }_{i}+\alpha_{9} \text { Liquidity } \__{-}-1_{i}+\alpha_{10} \operatorname{Ln}(\text { Leverage })_{i}+\varepsilon_{i} \text {. }
\end{aligned}
$$

Based on the correlation matrix, presented in Table 4, potential multicollinearity concerns can be eliminated. Because the correlation coefficients between variables separately for each model are all below 0.5 , there is no potential multicollinearity issue for the variables.

Table 5 presents results of logistic regression. 
TABle 3: Descriptive statistics.

\begin{tabular}{|c|c|c|c|c|c|c|c|}
\hline Variable & $N$ & Mean & Std. dev. & Mean error & Min. & Median & Max. \\
\hline Dividend & 678 & 0.354 & 0.479 & 0.018 & 0.000 & 0.000 & 1.000 \\
\hline Interlock & 678 & 0.709 & 0.454 & 0.017 & 0.000 & 1.000 & 1.000 \\
\hline Degree centrality & 678 & 0.003 & 0.004 & 0.000 & 0.000 & 0.002 & 0.026 \\
\hline Closeness centrality & 678 & 0.061 & 0.053 & 0.002 & 0.000 & 0.085 & 0.156 \\
\hline Betweenness centrality & 678 & 0.002 & 0.004 & 0.000 & 0.000 & 0.000 & 0.047 \\
\hline Eigenvector centrality & 678 & 0.006 & 0.034 & 0.001 & 0.000 & 0.000 & 0.325 \\
\hline Ln (age) & 678 & 7.347 & 0.990 & 0.038 & 2.565 & 7.463 & 8.630 \\
\hline Board size & 678 & 7.830 & 2.276 & 0.087 & 2.000 & 7.000 & 27.000 \\
\hline Ln (assets) & 678 & 11.196 & 2.225 & 0.085 & 5.918 & 11.104 & 22.091 \\
\hline $\mathrm{ROA}$ & 678 & 0.005 & 0.211 & 0.008 & -1.840 & 0.028 & 1.505 \\
\hline ROA_t $t-1$ & 678 & 0.016 & 0.202 & 0.008 & -1.594 & 0.033 & 1.142 \\
\hline Ln (sales) & 678 & 10.633 & 2.837 & 0.109 & -2.510 & 10.802 & 22.135 \\
\hline Cash & 678 & 0.018 & 0.119 & 0.005 & -0.996 & 0.004 & 0.801 \\
\hline Liquidity_t $t-1$ & 678 & 0.546 & 1.315 & 0.051 & 0.000 & 0.146 & 18.255 \\
\hline Ln (leverage) & 678 & 0.218 & 1.189 & 0.046 & -5.028 & 0.054 & 7.073 \\
\hline
\end{tabular}

A strategy of hierarchical estimation was used. In model 1 , the effect of the control variables on the dividend policy is presented. Only 3 out of 9 control variables are not statistically significant in relation to the dependent variables, Ln (Age), Ln (Assets), and Liquidity_t $t-1$.

Model 2 contains the independent variable Interlock, which determines whether the company has a network strategy using interlocking directorates. The absence of statistical significance of the independent variable's regression factor means that the networking factor has no impact on the likelihood of dividend payment to the parent company. Subsequent models took into account a deeper aspect of the network structure of the analyzed phenomenon.

Models 3-6 checked the hypothesis formulated in the paper that the higher the firm's board interlock centrality, the higher the probability that the dividend will be paid. In each of models 3-6 there is a different independent variable for the measurement of the company's centralization in the board interlocks network. Independent variables for models 3-5 are not statistically significant in relation to the dependent variable. It means that degree, closeness, and betweenness centrality variables do not affect the likelihood of dividend payment to the parent company. Model 6 contains independent variables, eigenvector centrality, statistically significantly related to the dependent variable at the significance level of $\alpha=0.01$. The final value of the loss function for model 6 is 327.415. The difference between the logarithm of reliability for model 6 compared to the model with only absolute term $\left(B_{0}\right)$ is 226.40 . This difference is statistically significant for $p<0.001$, which means that the model is fitted because it differs significantly only from the model with the absolute term. This means that the eigenvector centrality and control variables significantly affected the probability of dividend payment.

Based on the assessment of the model parameters, the general form of model 6 is as follows:

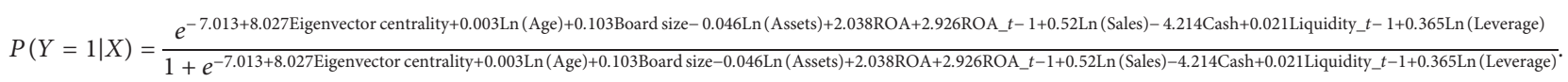

Considering additionally asymptotic standard errors, an equivalent form of model 6 was obtained:

$$
\begin{aligned}
& \operatorname{logit} P=-7.013+8.027 \text { Eigenvector centrality }+0.003 \operatorname{Ln}(\text { Age })+0.103 \text { Board size }-0.046 \operatorname{Ln}(\text { Assets })
\end{aligned}
$$

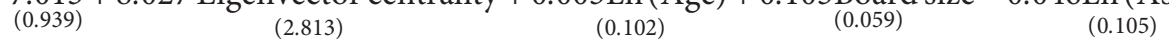

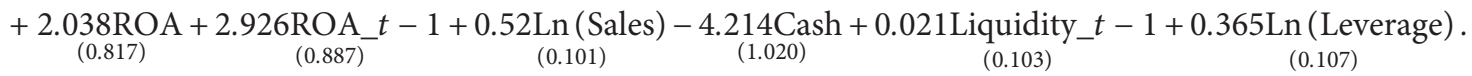

It should be noted that the pseudocoefficient $R^{2}$ McFadden, which is the equivalent of a determination coefficient for $R^{2}$ in standard regression analysis is $25.7 \%$. Modifications of pseudo $R^{2}$ in the form of $R^{2}$ Cox-Snell and $R^{2}{ }_{\text {Nagelkerke }}$ are $28.4 \%$ and $39.0 \%$, respectively. $R^{2}$ Nagelkerke is a transformation of $R^{2}{ }_{\text {McFadden }}$ in such a way that its maximum value is 1 . However, the calculated pseudocoefficients of $R^{2}$ in logistic 


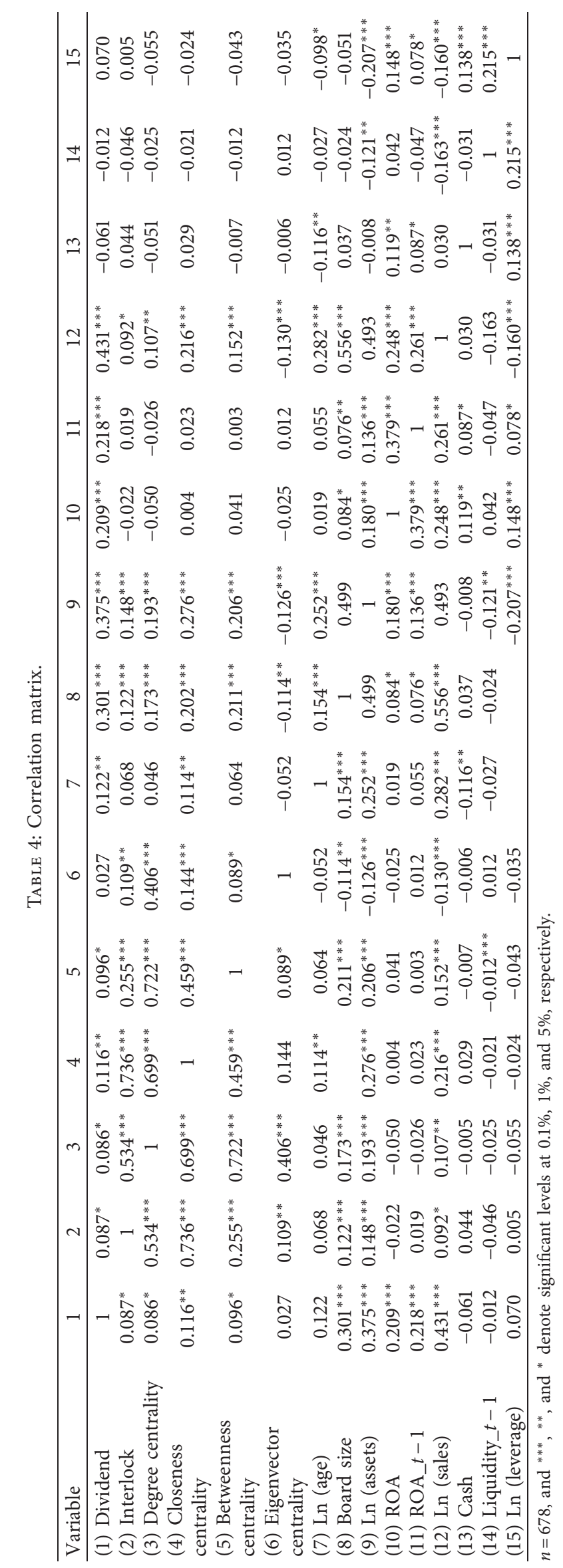


TABLE 5: Logistic regression analysis results (dependent variable $=$ Dividend).

\begin{tabular}{|c|c|c|c|c|c|c|}
\hline Variable & Model 1 & Model 2 & Model 3 & Model 4 & Model 5 & Model 6 \\
\hline Constant & $-6.638^{* * *}(1.003)$ & $\begin{array}{l}-6.630^{* * *} \\
(0.790)\end{array}$ & $\begin{array}{l}-6.581^{* * *} \\
(0.953)\end{array}$ & $\begin{array}{c}-6.665^{* * *} \\
(0.902)\end{array}$ & $\begin{array}{l}-6.580^{* * *} \\
(0.856)\end{array}$ & $\begin{array}{c}-7.013^{* * *} \\
(0.936)\end{array}$ \\
\hline Interlock & & $0.109(0.222)$ & & & & \\
\hline Degree centrality & & & $24.357(26.325)$ & & & \\
\hline Closeness centrality & & & & $-0.408(1.883)$ & & \\
\hline $\begin{array}{l}\text { Betweenness } \\
\text { centrality }\end{array}$ & & & & & $10.960(20.704)$ & \\
\hline Eigenvector centrality & & & & & & $8.027^{* *}(2.813)$ \\
\hline Ln (age) & $0.003(0.122)$ & $-0.001(0.070)$ & $0.002(0.110)$ & $0.004(0.096)$ & $0.002(0.086)$ & $0.003(0.102)$ \\
\hline Board size & $0.096^{\dagger}(0.058)$ & $0.093(0.058)$ & $0.090(0.058)$ & $0.097^{\dagger}(0.058)$ & $0.092(0.058)$ & $0.103^{\dagger}(0.059)$ \\
\hline Ln (assets) & $-0.035(0.103)$ & $-0.041(0.104)$ & $-0.052(0.105)$ & $-0.031(0.105)$ & $-0.043(0.104)$ & $-0.046(0.105)$ \\
\hline $\mathrm{ROA}$ & $2.133^{* *}(0.818)$ & $2.120^{* *}(0.815)$ & $2.130^{* *}(0.816)$ & $2.139^{* *}(0.818)$ & $2.113^{* *}(0.817)$ & $2.038^{*}(0.817)$ \\
\hline ROA_t $t-1$ & $3.117^{* * *}(0.876)$ & $3.086^{* * *}(0.877)$ & $3.110^{* * *}(0.876)$ & $3.123^{* * *}(0.876)$ & $3.127^{* * *}(0.876)$ & $2.926^{* * *}(0.887)$ \\
\hline Ln (sales) & $0.485^{* * *}(0.098)$ & $0.487^{* * *}(0.098)$ & $0.495^{* * *}(0.099)$ & $0.484^{* * *}(0.098)$ & $0.489^{* * *}(0.099)$ & $0.520^{* * *}(0.101)$ \\
\hline Cash & $-4.187^{* * *}(1.017)$ & $-4.182^{* * *}(1.014)$ & $-4.182^{* * *}(1.017)$ & $-4.194^{* * *}(1.017)$ & $-4.177^{* * *}(1.016)$ & $-4.214^{* * *}(1.020)$ \\
\hline Liquidity_t $t-1$ & $0.018(0.101)$ & $0.018(0.102)$ & $0.017(0.102)$ & $0.019(0.101)$ & $0.017(0.102)$ & $0.021(0.103)$ \\
\hline Ln (leverage) & $0.333^{* *}(0.106)$ & $0.333^{* *}(0.106)$ & $0.337^{* *}(0.106)$ & $0.334^{* *}(0.106)$ & $0.334^{* *}(0.106)$ & $0.365^{* * *}(0.107)$ \\
\hline Total loss & 331.429 & 331.429 & 331.003 & 331.406 & 331.289 & 327.415 \\
\hline$-2 \log L_{p}$ & 662.859 & 662.617 & 662.006 & 662.812 & 662.577 & 654.830 \\
\hline$-2 \log L_{0}$ & 881.233 & 881.233 & 881.233 & 881.233 & 881.233 & 881.233 \\
\hline Goodness of fit & 617.641 & 617.252 & 610.549 & 618.081 & 616.083 & 596.274 \\
\hline$x^{2}$ & $218.37^{* * *}$ & $218.37^{* * *}$ & $219.23^{* * *}$ & $218.42^{* * *}$ & $218.66^{* * *}$ & $226.40^{* * *}$ \\
\hline$R_{\text {McFadden }}^{2}$ & 0.248 & 0.248 & 0.249 & 0.248 & 0.248 & 0.257 \\
\hline$R_{\text {Cox-Snell }}^{2}$ & 0.275 & 0.275 & 0.276 & 0.275 & 0.276 & 0.284 \\
\hline$R_{\text {Nagelkerk }}^{2}$ & 0.379 & 0.379 & 0.380 & 0.379 & 0.379 & 0.390 \\
\hline
\end{tabular}

$n=678$, standard error in parentheses. ${ }^{* * *},{ }^{* *},{ }^{*}$, and ${ }^{\dagger}$ denote significant levels at $0.1 \%, 1 \%, 5 \%$, and $10 \%$, respectively.

regression do not directly inform about the goodness of fitting the model to the data, but it can be used in the analysis to determine which of the few models built is better fitted to the empirical data. It should be pointed out that all three types of coefficients of pseudo $R^{2}$ are the largest for model 6 , which means that attaching a network variable to the model increases the prediction of the independent variable. In relation to model 1 , which contains only control variables, pseudo $R^{2}$ coefficient are about 1 percentage point larger. The same applies to the comparison of model 6 with models $2-5$.

Table 6 presents the detailed results of regression analysis for model 6 .

The eigenvector centrality regression coefficient is positive, which means that higher values of centrality score correspond to a higher probability of dividend payment to the parent company. In addition, it can be concluded that with a $95 \%$ probability, the range of regression coefficients standing by independent variables is within the eigenvector centrality range $\langle 2.503 \div 13.55\rangle$.

The odds ratio for eigenvector centrality is greater than 1 , which means that the probability of dividend payment by the company increases in groups with a higher level of development of eigenvector centrality in the interlocking network. For the network variable in model 6 , the odds ratio is 3,061.467. The eigenvector centrality variable takes the values in the research sample in the range of $\langle 0 \div 0.325\rangle$, and the mean is 0.006 , cf. Table 3. Based on the odds ratio, the change in probability in a group of companies whose level of eigenvector centrality is exactly 0 (companies that do not have interlocking connections, their degree $=0$ ), and a group of companies that achieve eigenvector centrality at the average level (0.006) can be compared:

$$
\left(e^{8.02664949}\right)^{0.006}=3,061.467^{0.006}=1.05 \text {. }
$$

This means that, for companies in the group reaching the mean level of eigenvector centrality, the probability of dividend payment to the parent company increases more than 1.05 times when compared to isolated companies whose degree and, consequently, the level of eigenvector centrality is 0 . Exactly 1.5 fold increase in the probability of dividend payment (50\%) compared to companies isolated in the interlocking network is achieved by a group of companies whose degree of eigenvector centrality is 0.05 , which was estimated by solving the equation:

$$
\begin{aligned}
\left(e^{5.420357}\right)^{\text {Eigenvector centrality }} & =1.5, \\
225.96^{\text {Eigenvector centrality }} & =1.5, \\
\text { Eigenvector centrality } & =0.05 .
\end{aligned}
$$

The obtained value of eigenvector centrality is close to $15 \%$ of the maximum value in the research sample $(0.05 /$ $0.325)$.

The importance of the impact of a network variable on a dependent variable and the better fit of a model containing a network variable are important for the purpose of the study. The question is whether model 6 is better fitted by including a network variable (eigenvector centrality) in the model 
TABLE 6: Logistic regression analysis results for model 6.

\begin{tabular}{|c|c|c|c|c|c|c|c|}
\hline Model 6 & $b_{i}$ & Mean error & $t(667)$ & 95\% CL lower & 95\% CL upper & Wald $\left(\chi^{2}\right)$ & Odds ratio \\
\hline Constant & -7.013 & 0.936 & $-7.493^{* * *}$ & -8.851 & -5.176 & $56.145^{* * *}$ & 0.001 \\
\hline Eigenvector centrality & 8.027 & 2.813 & $2.853^{* *}$ & 2.503 & 13.550 & $8.142^{* *}$ & 3061.467 \\
\hline Ln (age) & 0.003 & 0.102 & 0.033 & -0.196 & 0.203 & 0.001 & 1.003 \\
\hline Board size & 0.103 & 0.059 & $1.750^{\dagger}$ & -0.013 & 0.219 & $3.064^{\dagger}$ & 1.109 \\
\hline Ln (assets) & -0.046 & 0.105 & -0.442 & -0.251 & 0.159 & 0.196 & 0.955 \\
\hline $\mathrm{ROA}$ & 2.038 & 0.817 & $2.495^{*}$ & 0.434 & 3.642 & $6.227^{*}$ & 7.675 \\
\hline ROA_t $t-1$ & 2.926 & 0.887 & $3.300^{* * *}$ & 1.185 & 4.667 & $10.888^{* * *}$ & 18.648 \\
\hline Ln (sales) & 0.520 & 0.101 & $5.152^{* * *}$ & 0.322 & 0.719 & $26.539^{* * *}$ & 1.683 \\
\hline Cash & -4.214 & 1.020 & $-4.130^{* * *}$ & -6.218 & -2.211 & $17.055^{* * *}$ & 0.015 \\
\hline Liquidity_t $t-1$ & 0.021 & 0.103 & 0.204 & -0.181 & 0.223 & 0.042 & 1.021 \\
\hline Ln (leverage) & 0.365 & 0.107 & $3.401^{* * *}$ & 0.154 & 0.576 & $11.565^{* * *}$ & 1.440 \\
\hline
\end{tabular}

$n=678$, and ${ }^{* * *},{ }^{* *},{ }^{*}$, and ${ }^{\dagger}$ denote significant levels at $0.1 \%, 1 \%, 5 \%$, and $10 \%$, respectively.

TABLE 7: Difference between models 6 and 1.

\begin{tabular}{lccccc}
\hline Maximum likelihood & \multicolumn{3}{c}{ Loss $=-2 \log L_{p}$} \\
Model $-2 \log L_{p}$ & Number of variables & Change in $-2 \log L_{p}$ & Change in $k$ variables & $p$ \\
\hline Value & 654.830 & 11 & 8.029 & 1 & 0.005 \\
\hline
\end{tabular}

when compared to model 1? Table 7 provides a relevant summary.

The value of the likelihood ratio (LR) test as the difference of the loss function $\left(-2 \log L_{p}\right)$ between models 6 and $1(662.859-654.830)$ as a result of the addition of the eigenvector centrality variable is 8.029 , which has a distribution close to $\chi^{2}$. This statistic tests the hypothesis.

$H_{0}: b_{1}=0$, meaning that the regression coefficient for the eigenvector centrality variable is 0 , so there is no statistically significant difference between the two models.

As the significance is $p=0.01$, which means that the $H_{0}$ hypothesis is rejected and the assumption that the eigenvector centrality variable attached to model 6 leads to a statistically significant difference when compared to model 1 is adopted. In other words, the eigenvector centrality variable significantly improves the fit of the model to empirical data, where a higher level of centralization in the interlocking network makes it more likely that dividends will be paid to the parent entity.

Table 8 shows the classification correctness coefficient and odds ratio for models 1 and 6. On the basis of model 6, better results of classification correctness of enterprises to a given group due to a dependent variable were obtained. The classification correctness for model 6 is $73.45 \%$. The odds ratio is the ratio of the product of correctly classified cases to the product of incorrectly classified cases $(368 * 125 / 115 * 70)$ for model 1 and $(369 * 129 / 111 * 69)$ for model 6 , respectively.

Table 9 presents the results of permutation test for logistic regression for model 6 . Permutation significance test randomly permuted vectors from original vector with $2,034,000$ number of iterations (3,000 permutation per observation). The expected value of the regression coefficient $\left(b_{i}, i=0,1, \ldots, k\right)$, as the average value in randomly permuted vectors is computed and then compared with the observed value. The original observed value of the regression coefficient is higher than the expected value for network variable, eigenvector variable, and the probability of such an occurrence is estimated to be 0.999 . Therefore, this is a strong position to state that the observed value of the regression coefficient is statistically significant.

Similarly, in the case of control variables-Board size, ROA, ROA_t-1, Ln (sales), Cash, and Ln (leverage)-the original observed values of the regression coefficients are statistically significantly different from the expected value.

Figure 2 shows the receiver operating characteristic (ROC) curve for model 6. The model shows a better assessment of the predictive capability if the ROC curve is close to the upper left corner of the coordinate system, as a result the area under the ROC curve is larger and the ROC index higher. A line inclined at $45^{\circ}$ means a reference line indicating the expected result of the classification of the model based on random prediction.

The ROC index, defined as AUC (area under the ROC curve), was 0.813 . The values of this index are in the range of $\langle 0 \div 1\rangle$, where the higher the ROC index values, the better the model rating. In probabilistic terms, the ROC index means the probability that the model determines a higher rank for randomly selected cases from positive target levels (variable Dividend =1) than for randomly selected cases from negative target levels (Dividend $=0$ ). ROC index values below 0.6 mean that the model is weak, and above 0.7 , it means that it is strong [135].

\section{Discussion}

The study showed that not all network variables, including centrality measures, are statistically significant in relation to the dependent variable. This applies to independent variables such as interlock, degree centrality, betweenness centrality, and closeness centrality. Centrality can be seen as a node's position that is as a source of opportunities and 
TABle 8: Case classification for models 1 and 6.

\begin{tabular}{lccccccc}
\hline \multirow{2}{*}{ Model } & Original dividend & Predicted dividend $=0$ & Predicted dividend $=1$ & Percentage correct & Odds ratio & Classification correctness \\
\multirow{2}{*}{ Model 1} & $\mathbf{0}$ & 368 & 70 & 84.02 & \multirow{2}{*}{5.714} & \multirow{2}{*}{72.71} \\
& $\mathbf{1}$ & 115 & 125 & 52.08 & & \multirow{2}{*}{73.45} \\
\multirow{2}{*}{ Model 6} & $\mathbf{0}$ & 369 & 69 & 129 & 53.25 & \multirow{2}{*}{6.215} & \\
& $\mathbf{1}$ & 111 & & & & & \\
\end{tabular}

TABle 9: Permutation significance test for logistic regression.

\begin{tabular}{|c|c|c|c|c|c|c|}
\hline (Model 6) variable & Observed & Expected (mean) & Std. dev. & $p($ mean $\geq$ Obs. $)$ & $p($ mean $=$ Obs. $)$ & $p($ mean $\leq$ Obs. $)$ \\
\hline Constant & -7.013 & -0.619 & 0.705 & 1 & 0 & 0 \\
\hline Eigenvector centrality & 8.027 & -0.265 & 2.808 & 0.001 & 0 & 0.999 \\
\hline Ln (age) & 0.003 & 0.003 & 0.088 & 0.491 & 0 & 0.509 \\
\hline Board size & 0.103 & -0.001 & 0.047 & 0.012 & 0 & 0.988 \\
\hline Ln (assets) & -0.046 & -0.002 & 0.067 & 0.747 & 0 & 0.253 \\
\hline $\mathrm{ROA}$ & 2.038 & 0.014 & 0.464 & 0 & 0 & 1 \\
\hline $\mathrm{ROA} \_t-1$ & 2.926 & 0.016 & 0.482 & 0 & 0 & 1 \\
\hline Ln (sales) & 0.52 & 0.002 & 0.053 & 0 & 0 & 1 \\
\hline Cash & -4.214 & -0.006 & 0.738 & 1 & 0 & 0 \\
\hline Liquidity_t $t-1$ & 0.021 & -0.006 & 0.074 & 0.362 & 0 & 0.638 \\
\hline Ln (leverage) & 0.365 & -0.003 & 0.076 & 0 & 0 & 1 \\
\hline
\end{tabular}

$n=678$.

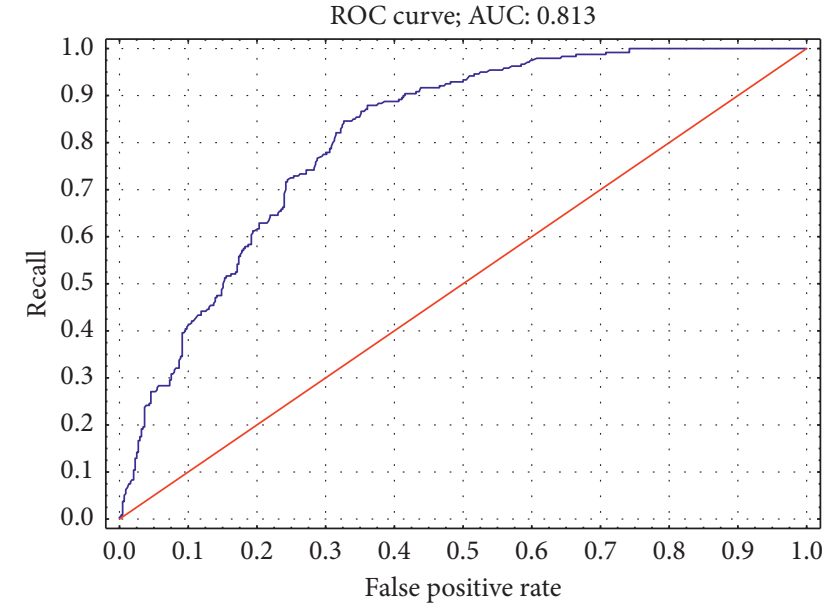

FIgURE 2: ROC curve for model 6.

advantage. Different centrality measures have different characteristics and capture various aspects of vertex position properties in the network. These measures also bring different information about the structure of the network.

The lack of dependence of participation in the interlocking network (interlock variable) on dividend payment results from insufficient information about the position in the network. In other words, the indication of the interlock network links does not guarantee an increase in the likelihood of dividend payments to the parent company. A similar result was obtained for the degree centrality, which takes into account the number of links in the network.

This means that neither a larger number of network relationships nor the mere indication of such relationships is significantly indistinguishable due to the modelled dependent variable. Although the better-connected directors are more experienced, powerful and competent in supervising firms, companies with more interlocked directors are not found to be more likely to payout dividends to the parent company in the ownership structure. More importantly is the position of the company in the board network structure. Degree centrality covers networked information flow only in an ego network structure. The degree of centrality does not take into account further connections beyond the company's closest neighbors in the network. It does not indicate the value of the relationship in the information flow network. Degree centrality is a standardized degree category, one of the basic network measures, which directly informs about the number of relationships with other companies in the network. However, it is a measure that covers ego network and does not allow for a wider context of indirect relationships within a wider network spectrum that includes pathway trajectory. In other words, degree does not take into account the network structure beyond the direct links. It is of limited application to the assessment of the interlocking strategy used by the undertaking. It does not indicate the value of a link in the information flow network. Many links to vertices on the periphery of the network cannot provide a substitute for a single link to a centrally networked company. Degree centrality should be seen as a measure of impact, enabling it to influence other companies to achieve their own goals [136], not the possibility of information transmission over the network. In this context, it was concluded that simply increasing the number of interlock network relationships leading directly to an increase in degree centrality does not significantly increase the flow of information on the network. This explains the lack of a statistically significant impact of demonstrating relationships in board interlock network (variable interlock) and changes in degree centrality in the modeled relationship. 
Closeness centrality and betweenness centrality are measures of centralities that are based on the trajectory of connections of any nodes along the shortest paths in the network. Betweenness centrality indicates the frequency of occurrence of the vertex on the geodesic paths between pairs of other nodes in the network, while centrality closeness is directly dependent on the geodesic distance between the vertex and other nodes in the network. As a result, the first of these measures should be interpreted more in terms of intermediation and control of information flow in the network, and the second measure in terms of the speed of information flow, depending on the distance from other nodes in the network only along the geodesic paths. Closeness centrality indicates the time of access to information appearing in nodes. The high position of closeness centrality enables the exchange of information in a shorter time and quick access to other enterprises on the network. This is not a key aspect for adopting the practice of paying dividends to the parent company. Contrary to a lot of information available through the network regarding market opportunities, the decision on dividend policy does not have to be made under time pressure. For these reasons, the relationship between the above measures of centralities and the payment of dividends to the parent company is not statistically significant. Considering only the connections along the shortest paths, the time of information flow (closeness centrality) as well as control and intermediation of information flow (betweenness centrality) are less important. The position of the company in the interlock network determined by means of centrality measures such as degree, closeness, or betweenness centrality is not sufficient to correctly assess the network diffusion of dividend payment practices to the parent company.

It has been shown that eigenvector centrality significantly influenced the propensity of paying dividend. Eigenvector centrality is a measure of the ability to transmit information in a network, taking into account all paths. The centrality of a node in the network is greater not only because of the number of links but also because of the centrality of the connected nodes. In other words, greater centrality results from relationships with vertices in a network with a high level of centrality. This makes it possible to shape the central position of an enterprise in the network from its structure, where the shortest paths are of equal importance to other possibilities of indirect links between companies. Eigenvector centrality is a measure of the ability to transmit information due to the existence of relationships with also highly connected enterprises. In this light, the panoramic context of the flow of information in the network, passing through a wider network structure than just the shortest paths in the network, is more important. This justifies the statement that the measure of eigenvector centrality is a more appropriate instrument for the measurement of organizational practices diffusion in social networks such as a dividend payment to the parent company in the ownership structure. The results of logistic regression indicate that the centrality of an enterprise in the network is important if its source comes from derived and reflected centrality, taking into account all paths in the network and not just the shortest. However, the number of relationships, closeness, and betweenness in the network resulting from the connection along the geodetic paths is irrelevant.

\section{Conclusions}

This study explored the link between the information flow within the board network and corporate financial decisions. In this study, information transmission between boards of directors was examined by studying the opportunity to adopt business practices through the interlock network. Specifically, the investigation was whether the various dimensions of a firm's centrality network affect corporate dividend policy. Board of directors seems to rely on social networks when making corporate policy decisions [9]. As corporate organizations form interlocking directorates, they create a social network of direct and indirect links with each other. This network can influence the information and corporate practices diffusion among enterprises [26]. This report provides evidence that corporate financial decisions can be adopted from other firms through board of directors and their connections in social networks. Consistent with the hypothesis of this study, it was observed that eigenvector centrality as a measure of network centrality within the interlock network, and it increases the probability of dividend payment to the parent company in the ownership structure.

Establishing links in the interlocking directorate network is associated with several benefits for the organization. One of them is the possibility of adopting organizational practices used in other companies. It is important to be able to establish such connections in order to ensure an appropriate level of centrality in the network, ensuring the implementation of the process of diffusion of organizational practices.

This study contributes to the literature in two primary ways. Firstly, it provides new evidence that contributes to the literature on the effect of social networks and the role of director networks on diffusion of practices in the field of corporate finance. Secondly, this study also contributes to the literature on the corporate governance. Findings of this study may have implications for board of directors, investors, and regulators.

Further research may focus on issues related to a wide range of corporate financial decisions and can be spread across firms through the influence of social networks including equity issuance, share repurchase, bond buyback, debt management strategy, or shaping of the capital structure.

\section{Data Availability}

The data that support the findings of this study are available in the supplementary material of this article.

\section{Conflicts of Interest}

The author declares that there are no conflicts of interest regarding the publication of this article. 


\section{Acknowledgments}

This research was supported by a grant financed by the National Science Center based on decision no. DEC-2013/ 11/B/HS4/00466.

\section{Supplementary Materials}

Dataset. (Supplementary Materials)

\section{References}

[1] Q. Liu, H. Li, X. Liu, and M. Jiang, "Information networks in the stock market based on the distance of the multi-attribute dimensions between listed companies," Physica A: Statistical Mechanics and Its Applications, vol. 496, pp. 505-513, 2018.

[2] W. Czakon and A. Kawa, "Network myopia: an empirical study of network perception," Industrial Marketing Management, vol. 73, pp. 116-124, 2018.

[3] R. Caiazza, A. A. Cannella, P. H. Phan, and M. Simoni, "An institutional contingency perspective of interlocking directorates," International Journal of Management Reviews, vol. 21, no. 3, pp. 277-293, 2019.

[4] J. Pfeffer and G. Salancik, The External Control of Organizations: A Resources Dependence Perspective, Stanford University Press, Stanford, CA, USA, 2013.

[5] P. Monge and N. Contractor, Theories of Communication Networks, Oxford University Press, Oxford, UK, 2003.

[6] M. H. Bazerman and F. D. Schoorman, "A limited rationality model of interlocking directorates," The Academy of Management Review, vol. 8, no. 2, pp. 206-217, 1983.

[7] Y. Yang and N. Cai, "Interlocking directorate and firm's diversification strategy: perspective of strategy learning," in Communications in Computer and Information Science, vol. 232, pp. 87-94, Springer, Berlin, Germany, 2011.

[8] G. T. Payne, G. S. Benson, and D. L. Finegold, "Corporate board attributes, team effectiveness and financial performance," Journal of Management Studies, vol. 46, no. 4, pp. 704-731, 2009.

[9] C. Fracassi, "Corporate finance policies and social networks," Management Science, vol. 63, no. 8, pp. 2420-2438, 2017.

[10] C. H. S. Bouwman and Y. Xuan, "Director overlap and firm financial policies," SSRN Electronic Journal, 2012.

[11] T. Koenig, R. Gogel, and J. Sonquist, "Models of the significance of interlocking corporate directorates," American Journal of Economics and Sociology, vol. 38, no. 2, pp. 173$186,1979$.

[12] M. S. Mizruchi, The Structure of Corporate Political Action, Harvard University Press, Cambridge, MA, USA, 1992.

[13] J. Galaskiewicz and S. Wasserman, "Mimetic processes within an interorganizational field: an empirical test," Administrative Science Quarterly, vol. 34, no. 3, p. 454, 1989.

[14] J. Bearden and B. Mintz, "Rationality and integration in the American interlocks network," in Networks of Corporate Power, F. Stokman, R. Ziegler, and J. Scott, Eds., pp. 234-249, Polity Press, Cambridge, UK, 1985.

[15] K. F. Hallock, "Reciprocally interlocking boards of directors and executive compensation," The Journal of Financial and Quantitative Analysis, vol. 32, no. 3, p. 331, 1997.

[16] L. H. H. Wong, A. F. Gygax, and P. Wang, "Board interlocking network and the design of executive compensation packages," Social Networks, vol. 41, pp. 85-100, 2015.

[17] N. Addy, X. Chu, and T. Yoder, "Voluntary adoption of clawback provisions, corporate governance, and interlock effects," Journal of Accounting and Public Policy, vol. 33, no. 2, pp. 167-189, 2014.

[18] R. Crespí-Cladera and B. Pascual-Fuster, "Executive directors' pay, networks and operating performance: the influence of ownership structure," Journal of Accounting and Public Policy, vol. 34, no. 2, pp. 175-203, 2015.

[19] G. F. Davis, "Agents without principles? The spread of the poison pill through the intercorporate network," Administrative Science Quarterly, vol. 36, no. 4, p. 583, 1991.

[20] G. F. Davis and H. R. Greve, "Corporate elite networks and governance changes in the 1980s," American Journal of Sociology, vol. 103, no. 1, pp. 1-37, 1997.

[21] P. L. Cochran, R. A. Wood, and T. B. Jones, "The composition of boards of directors and incidence of golden parachutes," Academy of Management Journal, vol. 28, no. 3, pp. 664-671, 1985.

[22] J. Wade, C. A. O'Reilly, and I. Chandratat, "Golden parachutes: CEOs and the exercise of social influence," $\mathrm{Ad}$ ministrative Science Quarterly, vol. 35, no. 4, p. 587, 1990.

[23] R. D. Kosnik, "Greenmail: a study of board performance in corporate governance," Administrative Science Quarterly, vol. 32, no. 2, pp. 163-185, 1987.

[24] E. Rogers, Diffusion of Innovations, Free Press, New York, NY, USA, 1983.

[25] M. Granovetter, "Economic action and social structure: the problem of embeddedness," American Journal of Sociology, vol. 91, no. 3, pp. 481-510, 1985.

[26] T. Chuluun, A. Prevost, and A. Upadhyay, "Firm network structure and innovation," Journal of Corporate Finance, vol. 44, pp. 193-214, 2017.

[27] C. Helmers, M. Patnam, and P. R. Rau, "Do board interlocks increase innovation? Evidence from a corporate governance reform in India," Journal of Banking \& Finance, vol. 80, pp. 51-70, 2017.

[28] E. Mazzola, G. Perrone, and D. S. Kamuriwo, "The interaction between inter-firm and interlocking directorate networks on firm's new product development outcomes," Journal of Business Research, vol. 69, no. 2, pp. 672-682, 2016.

[29] R. Srinivasan, S. Wuyts, and G. Mallapragada, "Corporate board interlocks and new product introductions," Journal of Marketing, vol. 82, no. 1, pp. 132-148, 2018.

[30] D. A. Palmer, P. D. Jennings, and X. Zhou, "Late adoption of the multidivisional form by large U.S. corporations: institutional, political, and economic accounts," Administrative Science Quarterly, vol. 38, no. 1, p. 100, 1993.

[31] N. Fligstein, "The spread of the multidivisional form among large firms, 1919-1979," Advances in Strategic Management, Emerald Group Publishing, vol. 17, pp. 55-78, Bingley, UK, 2000.

[32] H. Rao and K. Sivakumar, "Institutional sources of boundary-spanning structures: the establishment of investor relations departments in the fortune 500 industrials," Organization Science, vol. 10, no. 1, pp. 27-42, 1999.

[33] N. Fligstein, The Transformation of Corporate Control, Harvard University Press, Cambridge, UK, 1990.

[34] R. Chen, M. C. Dyball, and S. Wright, "The link between board composition and corporate diversification in Australian corporations," Corporate Governance: An International Review, vol. 17, no. 2, pp. 208-223, 2009.

[35] J. D. Westphal and E. J. Zajac, "Defections from the inner circle: social exchange, reciprocity, and the diffusion of board independence in U.S. corporations," Administrative Science Quarterly, vol. 42, no. 1, pp. 161-183, 1997. 
[36] W. Chua and R. Petty, "Mimicry, director interlocks, and the interorganizational diffusion of a quality strategy: a note," Journal of Management Accounting Research, vol. 11, pp. 93-104, 1999.

[37] B. Baysinger and R. E. Hoskisson, "The composition of boards of directors and strategic control: effects on corporate strategy," The Academy of Management Review, vol. 15, no. 1, pp. 72-87, 1990.

[38] M. A. Geletkanycz and D. C. Hambrick, "The external ties of top executives: implications for strategic choice and performance," Administrative Science Quarterly, vol. 42, no. 4, pp. 654-681, 1997.

[39] N. Ortiz-de-Mandojana, J. A. Aragón-Correa, J. DelgadoCeballos, and V. Ferrón-Vílchez, "The effect of director interlocks on firms' adoption of proactive environmental strategies," Corporate Governance: An International Review, vol. 20, no. 2, pp. 164-178, 2012.

[40] B. L. Connelly, J. L. Johnson, L. Tihanyi, and A. E. Ellstrand, "More than adopters: competing influences in the interlocking directorate," Organization Science, vol. 22, no. 3, pp. 688-703, 2011.

[41] J. R. Booth and D. N. Deli, "Factors affecting the number of outside directorships held by CEOs," Journal of Financial Economics, vol. 40, no. 1, pp. 81-104, 1996.

[42] M. A. Carpenter and J. D. Westphal, "The strategic context of external network ties: examining the impact of director appointments on board involvement in strategic decision making," Academy of Management Journal, vol. 44, no. 4, pp. 639-660, 2001.

[43] T. Perry and U. Peyer, "Board seat accumulation by executives: a shareholder's perspective," The Journal of Finance, vol. 60, no. 4, pp. 2083-2123, 2005.

[44] J. D. Westphal, M.-D. L. Seidel, and K. J. Stewart, "Secondorder imitation: uncovering latent effects of board network ties," Administrative Science Quarterly, vol. 46, no. 4, pp. 717-747, 2001.

[45] S. Battiston, E. Bonabeau, and G. Weisbuch, "Decision making dynamics in corporate boards," Physica A: Statistical Mechanics and Its Applications, vol. 322, pp. 567-582, 2003.

[46] A. V. Shipilov, H. R. Greve, and T. J. Rowley, "When do interlocks matter? Institutional logics and the diffusion of multiple corporate governance practices," Academy of Management Journal, vol. 53, no. 4, pp. 846-864, 2010.

[47] C. Shropshire, "The role of the interlocking director and board receptivity in the diffusion of practices," Academy of Management Review, vol. 35, no. 2, pp. 246-264, 2010.

[48] R. S. Burt, "Cooptive corporate actor networks: a reconsideration of interlocking directorates involving American manufacturing," Administrative Science Quarterly, vol. 25, no. 4 , p. $557,1980$.

[49] B. Boyd, "Corporate linkages and organizational environment: a test of the resource dependence model," Strategic Management Journal, vol. 11, no. 6, pp. 419-430, 1990.

[50] S. B. O’Hagan and M. B. Green, “Tacit knowledge transfer via interlocking directorates: a comparison of Canada and the United States," Geografiska Annaler: Series B, Human Geography, vol. 84, no. 1, pp. 49-63, 2002.

[51] S. B. O’Hagan and M. B. Green, “Corporate knowledge transfer via interlocking directorates: a network analysis approach," Geoforum, vol. 35, no. 1, pp. 127-139, 2004.

[52] M. Uddin, "Interfirm cooperation and information sharing through interlocking directorates," Management \& Marketing, vol. 10, no. 2, pp. 205-214, 2012.
[53] M. Simoni and R. Caiazza, "Interlocking directorates' effects on economic system's competitiveness," Business Strategy Series, vol. 14, no. 1, pp. 30-35, 2013.

[54] M. D. Howard, M. C. Withers, and L. Tihanyi, "Knowledge dependence and the formation of director interlocks," Academy of Management Journal, vol. 60, no. 5, pp. 19862013, 2017.

[55] T. R. Johansen and K. Pettersson, "The impact of board interlocks on auditor choice and audit fees," Corporate Governance: An International Review, vol. 21, no. 3, pp. 287-310, 2013.

[56] A. G. Davison, B. W. Stening, and W. T. Wai, "Auditor concentration and the impact of interlocking directorates," Journal of Accounting Research, vol. 22, no. 1, p. 313, 1984.

[57] C. Amstrong and D. Larcker, "Discussion of "the impact of the option backdating scandal on shareholders" and "taxes and the backdating of stock option exercise dates"' Journal of Accounting and Economics, vol. 47, no. 1-2, pp. 50-58, 2009.

[58] J. Bizjak, M. Lemmon, and R. Whitby, "Option backdating and board interlocks," Review of Financial Studies, vol. 22, no. 11, pp. 4821-4847, 2009.

[59] H. Rao, G. F. Davis, and A. Ward, "Embeddedness, social identity and mobility: why firms leave the NASDAQ and join the New York stock exchange," Administrative Science Quarterly, vol. 45, no. 2, pp. 268-292, 2000.

[60] P.-C. Chiu, S. H. Teoh, and F. Tian, "Board interlocks and earnings management contagion," The Accounting Review, vol. 88, no. 3, pp. 915-944, 2013.

[61] Y. Cai, D. S. Dhaliwal, Y. Kim, and C. Pan, "Board interlocks and the diffusion of disclosure policy," Review of Accounting Studies, vol. 19, no. 3, pp. 1086-1119, 2014.

[62] P. R. d. Cunha and M. R. Piccoli, "Influence of board interlocking on earnings management," Revista Contabilidade \& Finanças, vol. 28, no. 74, pp. 179-196, 2017.

[63] J. Han, N. Hu, L. Liu, and G. Tian, "Does director interlock impact the diffusion of accounting method choice?" Journal of Accounting and Public Policy, vol. 36, no. 4, pp. 316-334, 2017.

[64] E. Kang and B. R. Tan, "Accounting choices and director interlocks: a social network approach to the voluntary expensing of stock option grants," Journal of Business Finance \& Accounting, vol. 35, no. 9-10, pp. 1079-1102, 2008.

[65] D. A. Reppenhagen, "Contagion of accounting methods: evidence from stock option expensing," Review of Accounting Studies, vol. 15, no. 3, pp. 629-657, 2010.

[66] E. Noyes, C. Brush, K. Hatten, and L. Smith-Doerr, "Firm network position and corporate venture capital investment," Journal of Small Business Management, vol. 52, no. 4, pp. 713-731, 2014.

[67] J. L. Brown, "The spread of aggressive corporate tax reporting: a detailed examination of the corporate-owned life insurance shelter," The Accounting Review, vol. 86, no. 1, pp. 23-57, 2011.

[68] J. L. Brown and K. D. Drake, "Network ties among low-tax firms," The Accounting Review, vol. 89, no. 2, pp. 483-510, 2014.

[69] P. R. Haunschild, "Interorganizational imitation: the impact of interlocks on corporate acquisition activity," Administrative Science Quarterly, vol. 38, no. 4, p. 564, 1993.

[70] P. R. Haunschild, "How much is that company worth?: interorganizational relationships, uncertainty, and acquisition premiums," Administrative Science Quarterly, vol. 39, no. 3, p. 391, 1994. 
[71] T. E. Stuart and S. Yim, "Board interlocks and the propensity to be targeted in private equity transactions," Journal of Financial Economics, vol. 97, no. 1, pp. 174-189, 2010.

[72] F. Akbas, F. Meschke, and M. B. Wintoki, "Director networks and informed traders," Journal of Accounting and Economics, vol. 62, no. 1, pp. 1-23, 2016.

[73] L. Rossoni, C. E. Aranha, and W. Mendes-Da-Silva, "The complexity of social capital: the influence of board and ownership interlocks on implied cost of capital in an emerging market," Complexity, vol. 2018, Article ID 6248427, 12 pages, 2018

[74] D. Watts and S. Strogatz, "Collective dynamics of "smallworld" networks," Nature, vol. 393, no. 6684, pp. 440-442, 1998.

[75] D. J. Watts, "Networks, dynamics, and the small-world phenomenon," American Journal of Sociology, vol. 105, no. 2, pp. 493-527, 1999.

[76] D. J. Watts, Small-Worlds. The Dynamic of Networks between Order and Randomness, Princeton University Press, Princeton, NJ, USA, 1999.

[77] S. H. Strogatz, "Exploring complex networks," Nature, vol. 410, no. 6825, pp. 268-276, 2001.

[78] M. E. J. Newman, S. H. Strogatz, and D. J. Watts, "Random graphs with arbitrary degree distributions and their applications," Physical Review E-Statistical Physics, Plasmas, Fluids, and Related Interdisciplinary Topics, vol. 64, no. 2, p. 17, 2001.

[79] P. Erdös and A. Rényi, "On random graphs I," Publicationes Mathematicae, vol. 6, pp. 290-297, 1959.

[80] S. Battiston and M. Catanzaro, "Statistical properties of corporate board and director networks," The European Physical Journal B-Condensed Matter, vol. 38, no. 2, pp. 345-352, 2004.

[81] G. Caldarelli and M. Catanzaro, "The corporate boards networks," Physica A: Statistical Mechanics and Its Applications, vol. 338, no. 1-2, pp. 98-106, 2004.

[82] G. Robins and M. Alexander, "Small worlds among interlocking directors: network structure and distance in bipartite graphs," Computational \& Mathematical Organization Theory, vol. 10, no. 1, pp. 69-94, 2004.

[83] M. J. Conyon and M. R. Muldoon, "The small world of corporate boards," Journal of Business Finance \& Accounting, vol. 33, no. 9-10, pp. 1321-1343, 2006.

[84] G. Caldarelli, Scale-Free Networks: Complex Webs in Nature and Technology, Oxford University Press, Oxford, UK, 2013.

[85] B. Kogut, The Small Worlds of Corporate Governance, MIT Press, Cambridge, MA, USA, 2012.

[86] F. Bertoni and P. A. Randone, "The small-world of Italian finance: ownership interconnections and board interlocks amongst Italian listed companies," SSRN Electronic Journal, 2011.

[87] E. M. Heemskerk and G. Schnyder, "Small states, international pressures, and interlocking directorates: the cases of Switzerland and the Netherlands," European Management Review, vol. 5, no. 1, pp. 41-54, 2008.

[88] E. Sinani, A. Stafsudd, S. Thomsen, C. Edling, and T. Randøy, "Corporate governance in Scandinavia: comparing networks and formal institutions," European Management Review, vol. 5, no. 1, pp. 27-40, 2008.

[89] I. N. Durbach and H. Parker, "An analysis of corporate board networks in South Africa," South African Journal of Business Management, vol. 40, no. 2, pp. 15-26, 2009.

[90] R. Aguilera, "National state differences and patterns of directorship interlocks: a comparative study of Italy and
Spain," in Proceedings of the 2nd Summer Seminar on Sociological and Political Research, Cambridge, MA, USA, August 2008.

[91] C. Prem Sankar, K. Asokan, and K. Satheesh Kumar, "Exploratory social network analysis of affiliation networks of Indian listed companies," Social Networks, vol. 43, pp. 113120, 2015

[92] A. Sankowska and D. Siudak, "The small world phenomenon and assortative mixing in Polish corporate board and director networks," Physica A: Statistical Mechanics and Its Applications, vol. 443, pp. 309-315, 2016.

[93] E. F. Fama and M. C. Jensen, "Separation of ownership and control," The Journal of Law and Economics, vol. 26, no. 2, pp. 301-325, 1983.

[94] B. Baysinger and H. Butler, "Corporate governance and the board of directors: performance effects of changes in board composition," Journal of Law, Economics and Organization, vol. 1, pp. 101-124, 1985.

[95] B. Durisin and F. Puzone, "Maturation of corporate governance research, 1993-2007: an assessment," Corporate Governance: An International Review, vol. 17, no. 3, pp. 266-291, 2009.

[96] M. C. Jensen and W. H. Meckling, "Theory of the firm: managerial behavior, agency costs and ownership structure," Journal of Financial Economics, vol. 3, no. 4, pp. 305-360, 1976.

[97] N. Kumar and J. P. Singh, "Effect of board size and promoter ownership on firm value: some empirical findings from India," Corporate Governance: The International Journal of Business in Society, vol. 13, no. 1, pp. 88-98, 2013.

[98] J. Coles, N. Daniel, and L. Naveen, "Boards: does one size fit all?" Journal of Financial Economics, vol. 87, no. 2, pp. 329-356, 2008.

[99] C. H. Ong and D. Wan, "Three conceptual models of board role performance," Corporate Governance: The International Journal of Business in Society, vol. 8, no. 3, pp. 317-329, 2008.

[100] J. A. Brickley and J. L. Zimmerman, "Corporate governance myths: comments on Armstrong, Guay, and Weber," Journal of Accounting and Economics, vol. 50, no. 2-3, pp. 235-245, 2010.

[101] P. Stiles and B. Taylor, Boards at Work. How Directors View Their Roles and Responsibilities, Oxford University Press, Oxford, UK, 2010.

[102] C. H. S. Bouwman, "Corporate governance propagation through overlapping directors," Review of Financial Studies, vol. 24, no. 7, pp. 2358-2394, 2011.

[103] M. Rodriguez-Fernandez, S. Fernandez-Alonso, and J. Rodriguez-Rodriguez, "Board characteristics and firm performance in Spain," Corporate Governance: The International Journal of Business in Society, vol. 14, no. 4, pp. 485-503, 2014.

[104] J. Pfeffer, "Size and composition of corporate boards of directors: the organization and its environment," Administrative Science Quarterly, vol. 17, no. 2, p. 218, 1972.

[105] J. Pfeffer, "A resource dependence perspective on interorganizational relations," in Intercorporate Relations: The Structural Analysis of Business, M. S. Mizruchi and M. Schwartz, Eds., pp. 22-55, Cambridge University Press, New York, NY, USA, 1987.

[106] J. Światowiec-Szczepańska and M. Zdziarski, "Position in corporate network, performance and strategic risks," Problemy Zarzadzania, vol. 14, no. 4 (64), pp. 157-176, 2016.

[107] G. J. Nicholson, M. Alexander, and G. C. Kiel, "Defining the social capital of the board of directors: an exploratory study," 
Journal of Management \& Organization, vol. 10, no. 1, pp. 54-72, 2004.

[108] P. Windolf, Corporate Networks in Europe and the United States, Oxford University Press, Oxford, UK, 2008.

[109] L. Bohman, Interlocking Directorates and Director Recruitment: A Longitudinal Analysis of a 3-Mode Network, Stockholm University, Stockholm, Sweden, 2010.

[110] L. Bohman, "Bringing the owners back in: an analysis of a 3mode interlock network," Social Networks, vol. 34, no. 2, pp. 275-287, 2012.

[111] M. Ornstein, "Interlocking directorates in Canada: intercorporate or class alliance?" Administrative Science Quarterly, vol. 29, no. 2, p. 210, 1984.

[112] R. S. Burt, Corporate Profits and Cooptation. Networks of Market Constrains and Directorate Ties in the American Economy, Academic Press, New York, NY, USA, 1983.

[113] M. S. Mizruchi, "What do interlocks do? An analysis, critique, and assessment of research on interlocking directorates," Annual Review of Sociology, vol. 22, no. 1, pp. 271-298, 1996.

[114] F. D. Schoorman, M. H. Bazerman, and R. S. Atkin, "Interlocking directorates: a strategy for reducing environmental uncertainty," The Academy of Management Review, vol. 6, no. 2, pp. 243-251, 1981.

[115] E. R. Gansner, Y. Koren, and S. North, "Graph drawing by stress majorization," in Lecture Notes in Computer Science, vol. 3383, pp. 239-250, Springer, Berlin, Germany, 2004.

[116] TIBCO Software Inc., "Statistica (data analysis software system)," 2017, http://statistica.io.

[117] L. C. Freeman, "A set of measures of centrality based on betweenness," Sociometry, vol. 40, no. 1, p. 35, 1977.

[118] M. E. J. Newman, Networks: An Introduction, Oxford University Press, Oxford, UK, 2010.

[119] L. C. Freeman, "Centrality in social networks conceptual clarification," Social Networks, vol. 1, no. 3, pp. 215-239, 1978.

[120] S. Borgatti, M. Everett, and J. Johnson, Analyzing Social Networks, SAGE Publications, Thousand Oaks, CA, USA, 2013.

[121] C. Prell, Social Network Analysis: History, Theory and Methodology, SAGE Publications, Thousand Oaks, CA, USA, 2011.

[122] S. Wasserman and K. Faust, Social Network Analysis, Cambridge University Press, Cambridge, UK, 1994.

[123] M. O. Jackson, Social and Economic Networks, Princeton University Press, Princeton, NJ, USA, 2010.

[124] K. W. Koput, Social Capital: An Introduction to Managing Networks, Edward Elgar Publishing Ltd., Cheltenham, UK, 2010.

[125] T. W. Valente, Social Networks and Health: Models, Methods, and Applications, Oxford University Press, Oxford, UK, 2010.

[126] D. Knoke and S. Yang, Social Network Analysis, SAGE Publications, Thousand Oaks, CA, USA, 2008.

[127] M. Goergen, L. Renneboog, and Y. Zhao, "Insider trading and networked directors," Journal of Corporate Finance, vol. 56, pp. 152-175, 2019.

[128] S. Cheng, R. Felix, and Y. Zhao, "Board interlock networks and informed short sales," Journal of Banking \& Finance, vol. 98, pp. 198-211, 2019.

[129] S. P. Borgatti, "Centrality and network flow," Social Networks, vol. 27, no. 1, pp. 55-71, 2005.

[130] E. Croci and R. Grassi, "The economic effect of interlocking directorates in Italy: new evidence using centrality measures," Computational and Mathematical Organization Theory, vol. 20, no. 1, pp. 89-112, 2014.

[131] R. Grassi, "Vertex centrality as a measure of information flow in Italian corporate board networks," Physica A: Statistical Mechanics and Its Applications, vol. 389, no. 12, pp. 24552464, 2010.

[132] D. F. Larcker, E. C. So, and C. C. Y. Wang, "Boardroom centrality and firm performance," Journal of Accounting and Economics, vol. 55, no. 2-3, pp. 225-250, 2013.

[133] P. Bonacich, "Some unique properties of eigenvector centrality," Social Networks, vol. 29, no. 4, pp. 555-564, 2007.

[134] Cyram, NetMiner 4.4.3.B, Cyram Inc., Seoul, South Korea, 2019.

[135] J. Kelleher, B. Mac Namee, and A. D’Arcy, Fundamentals of Machine Learning for Predictive Data Analytics. Algorithms, Worked Examples, and Case Study, MIT Press, Cambridge, MA, USA, 2015.

[136] M. S. Mizruchi and D. Bunting, "Influence in corporate networks: an examination of four measures," Administrative Science Quarterly, vol. 26, no. 3, p. 475, 1981. 